DOI: $10.17516 / 1997-1370-0675$

УДК 342.2

\title{
Multivariance of the State Structure of Federalism (Comparative Historical and State Studies)
}

\author{
Aleksandr D. Gulyakov* \\ Penza State University \\ Russian Federation, Penza
}

Received 20.07.2020, received in revised form 17.09.2020, accepted 10.10.2020

\begin{abstract}
The article justifies the need for a historical-state study approach by analyzing the models of federalism inherent in different countries. The structural elements of any model include the prerequisites and reasons that contributed to federalization, essential characteristics of federalism (including the genesis characteristics, historical typology, development vector), the main stages of the federalism development.

Using the systemic and comparative methods, as well as the example of three first settlement models inherent in the USA, Canada, Australia, one European (German) and Russian models, the author shows and explains the features of federalism in these countries. In particular, there are more favorable conditions for the formation of federations in the first settlement societies and the well-known difficulties of their establishment in Europe (on the example of Germany). The article demonstrates the ideologically innovative nature of Soviet federalism and the rational construction of Russian (post-Soviet) federalism, which has not abandoned a high degree of centralization.

The materials presented in the article allow not only to outline new features of the state structure of federalism, but also contribute to the development of the concept for reforming federative relationships.
\end{abstract}

Keywords: federalism, federalism models, first settlement federalism, European federalism, stages of federalism development, comparative federalism.

Research area: law.

Citation: Gulyakov, A.D. (2020). Multivariance of the state structure of federalism (comparative historical and state studies). J. Sib. Fed. Univ. Humanit. Soc. Sci., 13(10), 1687-1695. DOI: 10.17516/1997-13700675 .

(C) Siberian Federal University. All rights reserved

* Corresponding author E-mail address: valeriya_zinovev@mail.ru ORCID: 0000-0002-6446-8142 


\section{Introduction}

A keen interest in the problem of federal states has been observed only in the last two centuries, i.e. from the moment they actually appeared. These states did not immediately prove their effectiveness. Initially, statesmen and political philosophers of the Old World treated them with disdain and prejudice, especially in the main states of Western Europe at that time - Great Britain (Kendle, 2004: 28-31) and France (Dyugi, 2005: 171). The situation began to change only from the beginning of the 20 th century, as the process of state building became more complicated. The two-level autonomy of the power organization in the center and in the subjects within the framework of a single state began to be taken for granted. As a result, currently there are about three dozen federations on different continents. Are their state structures something uniform, standard, or are there any prevailing specific features?

\section{Conceptual basis of the research}

Researchers studying federalism have traditionally focused more on theoretical issues; in particular, the divisibility or indivisibility of sovereignty or the classification of federations in terms of their legal nature. The theme of sovereignty was very popular in the 19th century and was politically short-term (Ebzeev, 2017: 14). It was used to justify centralized or, conversely, decentralized federations, as well as confederations. Ultimately, in German science, where it was most actively discussed, the approach in favor of centralization prevailed. This is evidenced by the works of the patriarchs of constitutionalism: G. Jellinek, P. Laband, R. Mohl (Geymbuh, 2009: 21-27). In modern science, it is recognized that in a federal state it should not be about the division of sovereignty between the federation and its constituent entities, but the coexistence, interdependence and interaction of two different-level sovereignties when each of them cannot successfully develop in isolation from the other (Tadevosyan, 2001: 148).

Another issue associated with the allocation of treaty and constitutional federations is also quite abstract. In fact, "the differences between treaty and constitutional federations are largely arbitrary". One and the same federation is initially established as a result of certain agreements, and then enshrined in the constitution.

"Moreover, elements of the contractual process and constitutional settlement can develop in parallel" (Sravnitelnaya politologiya, 2015: 322). Therefore, a slightly different classification is proposed: constitutional, contractual-constitutional, constitutional-contractual federations (Grachev, Ermyalieva, 2007). However, no matter which version we adhere to, it is obvious that the problem of federations, and in a broader sense of federalism, does not tolerate one-dimensional assessments, but requires a comparative approach.

\section{Problem statement}

Federalism is a much more large-scale phenomenon than federation. It is difficult to agree that federalism and federation are the elements of the same rank in the federative system as A.K. Rodionova states (Rodionova, 2011: 133-135). However, both federation and federalism require a more detailed and comprehensive study.

We should consider federation and federalism from a slightly different angle - not from the standpoint of constitutional law or political science, but from a historical and state-related perspective. This phenomenon should be viewed not as static 'pictures', but as a complex dynamic process. About two decades ago, in a fundamental collective monograph of Russian historians and lawyers, it was noted that "federalism is not a one-dimensional, but a multidimensional phenomenon, and it is not only static but also dynamic" (Federalizm, 2000: 18). Structurally, federalism includes federation as one of the forms of government, ideas, theories and principles, processes of federalization and de-federalization, and federalist culture (Farukshin, 2004: 51). However, what can the proportion between these or other elements be in relation to each other? After all, apparently, federalism is not just a set of certain elements, but their system. Moreover, we have the right to assume that different countries have their own variants or models of federalism and they should be compared with each other. 


\section{Methods}

A systematic approach is of key importance in the study of the federalism models, since within its framework it is possible to consider federalism as a dynamic system.

It should certainly include "knowledge about the process of forming federations, which is called "federalization"” (Brezgulevskaya, 2004: 46). The basis of this knowledge is made up of prerequisites (or long-term conditions for the beginning of processes) and causes (i.e. circumstances arising suddenly as a reaction to a changing historical context) (Ivshina, 2014: 98). However, this is clearly not enough. It is necessary to identify such essential characteristics as the genesis variety (i.e. federalism, from the point of view of its active or passive support by the population, could have been formed 'bottom-up', 'top-down' or in a mixed way), its historical typology (or connection with a specific era and country), vector of development (centripetal or centrifugal).

Finally, the dynamic component in the form of developmental stages is extremely important, as each of them has its own characteristics and duration (Malko, Gulyakov, Salomatin, 2018: 120-121).

The federalism model of each country with its certain set of properties, is unique in its own way. Models need to be compared using synchronous and diachronous analysis (Malko, Salomatin, 2018: 75), applying binomial and polynomial comparison. For example, it is expedient to compare the models of immigration federalism (USA, Canada, Australia) with each other. At the same time, it is interesting to compare one of the most striking models of this type, which is American, in pairs with models of other types - German and Russian.

\section{Discussion}

The analysis of the models should begin with the most classic example among them, the American one, not because it is 'the most correct' one, but simply because it is the earliest in time of its appearance.

Federalization of the former British colonies in North America had quite weighty prerequisites and reasons. The confederate structure implemented in accordance with the
Articles of Confederation of 1778 after the end of the 1775-1783 War of Independence proved to be completely untenable (Filimonova, 2007: 93-94). The supreme unicameral representative body even had elementary problems with the quorum (Shiryaev, 1981: 19). The model of the federal structure developed during the constitutional convention of 1787, established an optimal presidential republic for the given situation, with a consistent division into branches of government and a classical scheme of checks and balances. It was stated that "powers not delegated to the United States by this Constitution and not prohibited for individual states are reserved, respectively, for the states or for the people" (Soedinennye Shtaty Ameriki..., 1993: 42).

The model of American federalism that was implemented later, was dynamic, migrant and hegemonic. The boundaries of the settlements were rapidly moving inland, to the west, and the number of states was increasing sharply. After overcoming the conflict between the northern (free) and southern (slave) states during the Civil War of 1861-1865 the longterm tendency towards centralization completely prevailed in the country. By the end of the 19th century the hegemonic orientation of American federalism, which relied not only on gigantic internal material resources, but also on external military-political and economic expansion, as well as the ideology of 'American exceptionalism', was fully revealed (Gulyakov, 2020: 118).

The United States went through an extremely long stage of dualistic federalism, in which the center and the constituent entities had a pronouncedly autonomous scope of powers. However, with the strengthening of state regulation since the end of the $19^{\text {th }}$ century a gradual transition to cooperative federalism is observed. Now, since the middle of the $20^{\text {th }}$ century, the federal center had been providing broad financial assistance to the subjects. "State and national agencies tend to perform government functions jointly rather than separately" (Dzhanda et al., 2006: 126). However, by the end of the 20th century management approaches change again: the concept of competing federalism is announced. It "focuses on 
issues of competition between government levels...". Its supporters "project economic models onto the sphere of federal relations" (Lafitskiy, 2011: 182-183).

However, in the past decade, the well-being of the American state has been called into question. Against the background of an acute cultural and civilizational crisis between white conservative-minded Republicans and cosmopolitan, neoliberal-minded democrats of predominantly different ethno-racial roots, federalism becomes 'fragmented', which means a dangerously high level of political differentiation between states, as well as between states and the federal center (Bowling, Picrerill, 2013: $1-2)$.

In neighboring Canada, with a delay of three quarters of a century, immigration federalism is also being established, but it is not formed "bottom-up", on a broad democratic basis, as in the United States, but in a mixed way - at the initiative of individual regional elites, with the passive role of ordinary Canadians, but with an active support of the authorities of the metropolis. Without the consent and action of London, which put pressure on the governors of the two colonies who opposed the unification (Rayerson, 1970: 304), and without its help in taking huge territories from the Hudson's Bay Company and transferring them to the young state (Volodin, 2018: 89-90) Canada would not have appeared.

The British North America Act of 1867 which established a federation in the form of a dominion (i.e. a dependent territory), attracts attention by a more complex structure than the US Constitution of 1787. There is a desire to control many issues as much as possible, including those beyond the competence of the federal center. The center is endowed with 29 powers, the provinces with 15 exclusive powers. At the same time, in contrast to the Constitutions of Austria, Brazil, Germany, the Russian Federation, the sphere of joint competence is not provided (Danilov, 2012: 52).

The Founding Fathers of Canada, highly critical of the Civil War-torn US, sought a centralized (imperial-colonial) model of federalism. At the same time, Canadian federalism faced an amazing historical paradox: the de- gree of its centralization did not increase over time, as in other federations, but weakened. Apparently, the initial bilingual and biconfessional structure of the state, in which, along with the Anglo-Canadian majority, French Canadians lived compactly, caused difficulties for it in the implementation of the centripetal vector (Salomatin, Seidov, 2020: 70). However, there were other reasons as well. The stage of imperial-colonial federalism ended very quickly by the end of the 19th century, and the stage of classical (dualistic) federalism also did not last long, being interrupted by the Great Depression of the 1930s. At the same time, cooperative federalism which came under the conditions of intensified intergovernmental relations (late 1930s-1960s), proceeded against the background of strengthening the economic independence of the provinces. The problem of the separatist-minded French-speaking Quebec, which has exacerbated since the late 1960s, only further stimulated this independence. Central government at the turn of the 1980s-1990s nearly weakened the state critically, preparing to make unjustified concessions to Quebec. However, even after abandoning plans for universal decentralization, Canada is the most decentralized federation in the world. At the same time, there is no threat of a cultural and civilizational split similar to the one in the United States in the near future.

The Australian version of immigration federalism is distinguished by the latest start. The development of Australia began only from the very end of the $18^{\text {th }}$ century and due to its exceptional remoteness up to the middle of the $19^{\text {th }}$ century it was progressing extremely slowly. On the other hand, the critical labor shortage has created very favorable socio-economic conditions for workers here and contributed to the strengthening of trade unions (Skorobogatykh, 2011: 48, 34).

As in the United States and Canada, there were quite real prerequisites for federalization in Australia, but the immediate reasons were not yet fully ripe. If the joint experience of the states in the struggle for independence played a very significant role in the formation of the United States, and subsequently fears of the 
intervention of European powers, if in the formation of Canada much is explained by the fear of the Canadian elite and British colonial authorities of American expansion, then the motives for unification for the regional Australian elites were rather far-fetched than real, and the interest of the metropolis turned out to be low. Therefore, the movement towards federation resembled a multi-way combination of many meetings and conventions (La Nauze, 1972), which lasted a whole decade and ended with the adoption of the Constitution of the Commonwealth of Australia in 1900.

Like the corresponding constitutional act for Canada of 1867, it built the so-called Westminster system of government, providing for the formation of a government responsible to parliament under a constitutional monarchy.

Pre-tested in the Canadian provinces in 1848 and six Australian colonies in 1855-1890 (Fieldhouse, Madden, 1990), the constitution fixed broad powers of the governor-general as the representative of the crown, including the right to dissolve both chambers of parliament and appoint members of the government. As for the parliament itself, it was more democratically organized than the supreme representative body of Canada, in which the upper house was not elected. The founding fathers of Australia turned out to be more restrained in relation to the central government than their $\mathrm{Ca}$ nadian counterparts. Here, "labor regulation, finance, taxes, insurance, banking, railway construction, maritime law, etc. were jointly administered by the federation and the states" (Skorobogatykh, 2006: 6).

Australia, unlike Canada, borrowed a lot from the constitutional practice of the United States, which it treated with great respect. It also had a gradually increasing centripetal vector of development, the main instrument of which was the financial dependence of the states on the federal center. The stage of dualistic federalism continued here until World War II, and was replaced by cooperative federalism. Against the background of adjustments to federal policy since the late 1970s the doctrine of competitive federalism is spreading here, which, unlike the US and Canada, does not make the country weaker.
The rise of federalism in Europe was significantly different from the advancement of first settlement federalism beyond its borders. First of all, there were very active opposing forces associated with the high population density and long-standing conflicts of neighboring states, as well as feudal-bureaucratic vestiges that hindered the organization of more complex, democratic forms of the state. The Holy Roman Empire of the German nation weakly bound by a confederation (Yaschenko, 1912: 653), had been accumulating the prerequisites for a closer unification of Germany over a millennium, but weighty reasons (economic, military, foreign policy) for the implementation of the latter appear only in the 1860s. The unification of Germany within the framework of the imperial federation took place only in 1871 by 'top-down' efforts, at the initiative of the most powerful state, which does not have the ability to carry out many administrative functions with the help of the central apparatus. Administrative federalism here not only replaced dualistic federalism, but also retained its influence later, during the Weimar Republic in 1919-1933 and after 1945.

At the same time, German federalism at the turn of the 19th-20th centuries was monarchic and hegemonic (Kastel, 1995: 10), since it provided not only the hegemony of Prussia within Germany, but also the desire for expansion to the European continent.

After World War II, cooperative federalism with a moderate degree of centralization prevailed in Germany. Its territorial and administrative structure was formed anew, without taking into account age-old traditions (Hesse, 1981: 116).

Germany is a parliamentary republic with a proper and at the same time flexible level of representation of the subjects. Preserving the tradition of respectful attitude towards the authorities of the lands of the German Empire times, the Bundesrat is not just an ordinary second, upper house of the parliament, but a completely autonomous body with delegates from the state governments. Its position is weaker than the position of the lower house - the Bundestag, "but at the same time its constitutional and legal position is stronger than that of many 
other second houses in England and France) ..." (Zonthaymer, 1996: 260).

In contrast to the countries of the first settlement federalism, Germany is more active in the implementation of constitutional and legal reforms. They were held repeatedly: in the 1960s, in 1994 - after the accession of the GDR, in 2006 and 2009. The concept of competitive federalism launched in the 1990s has not yet received a priority: it has both supporters (primarily among the rich lands and in the $\mathrm{CDU} / \mathrm{CSU}$ parties) and opponents (among the poor lands and social democrats). However, once again in Germany, unlike in the United States, there is no dangerous fragmentation in society. German federalism is quite viable.

Our Russian federalism is also viable. It became the heir to Soviet federalism, which in turn was able to rely on the powerful centuries-old prerequisites of the complex Russian empire (Gulyakov, Salomatin, 2019). In turn, after the collapse of the autocracy and the end of the Civil War, specific reasons were formed that favored rapid federalization. The landmarks of proto-federalization were: 1) the organization of a complex, nationally structured RSFSR and its consolidation in the Constitution of 1918 ; 2) the conclusion of bilateral union treaties with Soviet republics outside the RSFSR; 3) discussion of the final legitimation of allied relations and the victory of the Leninist version over the Stalinist one. The constitutional consolidation of the developed federalization plan was accomplished quickly - in the period from December 1922 (signing of the Treaty on the establishment of the USSR) to January 1924 (adoption of the Constitution of the USSR). As in Germany in 1871, federalization in our country was carried out 'top-down', i.e. through the efforts of the ruling Marxist-Leninist party.

The Soviet model of federalism was characterized by a consistent centripetal vector and it went through several stages. In the 1920s there was dualistic-centralized federalism: the country's leadership could not and did not want to sharply strengthen the powers of the center, especially since until the end of the 1920s there was an acute ideological and political struggle in the leadership of the state party. However, in the face of the beginning industrialization and collectivization the USSR in the early 1930s transfers to authoritarian-mobilization federalism, which lasts until the 1960s including. This period is accompanied by bureaucratic centralization and often voluntaristic decisions. The promotion of slogans about the Soviet people as a new historical community of people in the 1970s marks the transition to ideological-bureaucratic federalism. However, unfortunately, noisy propaganda campaigns about the achieved success of interethnic integration cannot replace solving real problems. Due to a complex set of objective reasons and subjective circumstances (Gulyakov, 2020: 311), the USSR collapsed, and within the Russian Federation in the 1990s there is a movement towards confederal federalism. The "parade of sovereignties' brings Russia to a dangerous line (Andrichenko, Yurtaeva, 2013: 5). The stage of strengthening the positions of the federal center at the beginning of the 21st century leads to the construction of a rigid vertical of power. At the same time, as globalization processes unfold in the world and global instability intensifies after the financial and economic crisis of 2008, it becomes more and more urgent to adapt federal relations to new realities.

\section{Conclusion}

Considering only a few models of federalism on the example of 5 countries justifies their undoubted originality. Most researchers have traditionally studied the general features of federalism with greater scrutiny, but have not paid attention to its features in different countries. Meanwhile, the features turn out to be much more interesting and important. They prompt us to see the historical possibilities and limitations of the federal state, the achievements and failures of the federal state-legal policy. We cannot talk about the ideal version of the state structure of federalism, but a comparative analysis helps us to understand that, for example, federalization was easier to carry out in the first settlement societies, but this does not mean that these models themselves were more effective. In any case, the concept of competitive federalism would be hardly worth applying in Russia or Germany. The high level of centralization of Russian federalism is its 
undoubted historical benefit, but, apparently, it also needs some restoration of the balance in the direction of a targeted expansion of the independence of the regions. Perhaps the German, but not the American, and not the Cana- dian experience, could be useful here. Such an analysis is especially relevant if we strive to improve federal relations (Gulyakov, 2020). This task is far from trivial, and it requires both new approaches and extensive factual material.

\section{References}

Andrichenko, L.V., Yurtaeva, E.A. (2013). Konstitutsionnye osnovy rossiyskogo federalizma [The constitutional foundations of Russian federalism]. In Zhurnal rossiyskogo prava [Journal of Russian Law]. $6,5-16$

Brezgulevskaya, N.V. (2004). Federatsiya i federalizm: vidy i modeli [Federation and federalism: types and models]. In Pravo i politika [Law and Politics], 7, 45-48.

Bowling, C.J., Picririll, J.M (2013). Fragmental Federalism. The State of American Federalism 201313 In Publius, The Journal of Federalism.

Castel E.R. (1995). Germaskii federalism: istiriko-pravovoeissledovanie [German federalism: historical and legal research] (1849-1990). Abstract for the degree of doctor of law. Yekaterinburg, $422 \mathrm{p}$.

Danilov, S.Yu. (2012). Evolyutsiya kanadskogo federalizma [The evolution of Canadian federalism]. Moscow, Izdatelskiy dom Vyisshey shkolyi ekonomiki, 303 p.

Dugi, L. (2005). Konstitutsionnoe pravo. Obshchaia teoriia gosudarstva [Constitutional law. General theory of the state]. St. Petersburg, SPb. State University, $988 \mathrm{p}$.

Ebzeev, B.S. (2017). Globalizatsiya i stanovlenie transnatsionalnogo konstitutsionalizma [Globalization and the emergence of transnational constitutionalism]. In Gosudarstvo i pravo [State and law]. 1, 5-15.

Fieldhouse, D., Madden, F. (1990). Settler self-government, 1840-1900. New York, Greenwood Press, 834 p.

Farukshin, M.H. (2004). Federalizm: teoreticheskie i prikladnyie aspekty [Federalism: theoretical and applied aspects]. Moscow, Yurist, $527 \mathrm{p}$.

Federalizm: teoriya i istoriya razvitiya (sravnitelno-pravovoy analiz) [Federalism: theory and history of development (comparative legal analysis)], Tomsk, Izdatelstvo Yurist, 258 p.

Filimonova, M.A. (2007). Soedinennyie Shtaty na puti k konsolidatsii. Politicheskaya bor'ba $v$ kontinentalnom Kongresse. 1781-1788 [The United States Towards Consolidation. Political struggle in the continental Congress. 1781-1788]. Moscow, IVI. RAN, 278 p.

Geymbuh, N.G. (2009). Konstitutsionno-pravovoe voploshchenie idei nemetskogo edinstva [Constitutional and legal embodiment of the idea of German unity]. Tomsk, Izdatelstvo "Veter", 204 p.

Grachev, N.I., Ermyasheva N.A. (2007). Suverenitet federativnogo gosudarstva: problemyi teorii $i$ konstitutsionnogo regulirovaniya [The sovereignty of a federal state: problems of theory and constitutional regulation]. Volgograd, Institut ekonomiki, sotsiologii i prava, 258 p.

Gulyakov, A.D. (2020). Federalizm: mekhanizm vozniknoveniya i osnovnyie napravleniya razvitiya: istoriko-gosudarstvovedcheskoe issledovanie: monografiya [Federalism: the mechanism of occurrence and the main directions of development: historical and state research: monograph]. Moscow, RIOR-INFRA-M,388 p.

Gulyakov, A.D. (2020). Kontseptsiya gosudarstvenno-pravovoy politiki v sfere federativnyih otnosheniy (proekt) [The concept of state legal policy in the field of federal relations (draft)]. Penza, izdatelstvo PGU, 36 p.

Gulyakov, A.D., Salomatin, A.Yu. (2019). Kak nashe gosudarstvo stalo federativnym? (analiz otechestvennogo istorko-gosudarstvovedcheskogo opyta) [How did our state become federal? (analysis of domestic source-state experience)]. Penza, izdatelstvo PGU, 150 p.

Hesse, K. (1981). Osnovyi konstitutsionnogo prava FRG [Fundamentals of constitutional law of Germany]. Moscow, Izdatelstvo Yuridicheskaya literatura, 368 p. 
Ivshina, K.N. (2014). Sozdanie federativnogo gosudarstva [Creation of a federal state]. Moscow, Izdatelstvo Yurlitinform, $328 \mathrm{p}$.

Kendle, J. (2004). Federal Britain. A History. Routledge, London, 204 p.

La Nauze, J.A. (1972). The Making of the Australian Constitution. Melbourne, Melbourne University Press, $369 \mathrm{p}$.

Lafitskiy, V.I. (2011). Konstitutsionnyi stroy SShA. 2-e izd [The constitutional system of the United States. 2nd ed], Moscow, Statut, $354 \mathrm{p}$.

Malko, A.V., Gulyakov, A.D., Salomatin, A.Yu. (2018). Federalizm v istoriko-gosudarstvovedcheskom izmerenii [Federalism in the historical-state science dimension]. In Gosudarstvo i pravo [State and law], 12, 116-127.

Malko, A.V., Salomatin, A.Yu. (2008). Sravnitelnoe pravovedenie [Comparative Law]. Moscow, Izdatelstvo Norma, $352 \mathrm{p}$.

Rayerson, S.B. (1970). Neravnyi soyuz. Istoriya Kanadyi [Unequal union. History of Canada, 18151873], Moscow, Progress, 398 p.

Rodionova, A.K. (2011). Institutsional'nye osnovy federalizma [Institutional foundations of federalism]. Irkutsk, $202 \mathrm{p}$.

Salomatin, A.Yu., Seidov, Sh. (2020). K voprosu ob etnopoliticheskoy ustoychivosti federatsiy (sravnitelnyiy analiz opyita Kanadyi, SShA, RF) [On the ethnopolitical stability of federations (a comparative analysis of the experience of Canada, the USA, and the Russian Federation)]. In Vestnik Rossiyskoy natsii [Bulletin of the Russian nation], 1(71), 69-77.

Skorobogatykh, N.S. (2011). Istoriya Avstralii [History of Australia]. Moscow, Izdatelstvo Institut stran Vostoka, $240 \mathrm{p}$.

Skorobogatykh, N.S. (2006). Vekhi konstitutsionnogo puti Avstralii (1788-2000 gg.) [Milestones of Australia's Constitutional Path (1788-2000)]. Moscow, Institut vostokovedeniya RAN, 236 p.

Soedinennye Shtaty Ameriki. Konstitutsiya i zakonodatelnyie aktyi [United States of America. Constitution and Legislation] (1993). Moscow, Izdatelskaya gruppa "Progress" "Univers", 768 p.

Sravnitelnaya politologiya [Comparative Political Science] (2015). Moscow, Izdatelstvo "Aspekt Press", 752 p.

Shiryaev, B.A. (1981). Politicheskaya bor'ba $v$ SShA 1783- 1801 gg [Political struggle in the USA 17831801]. Leningrad, Izdatelstvo Leningradskogo universiteta, $200 \mathrm{p}$.

Tadevosyan, E.V. (2001). Problemy rossiyskogo federalizma, Sotsiologicheskie issledovaniya [Problems of Russian federalism]. In Sotsiologicheskie issledovaniya [Case studies], 7,145-150.

Volodin, D.A. (2018). Kak Kanada stala arkticheskoy derzhavoy [How Canada became an Arctic power]. In Institut SShA $i$ Kanady RAN [Institute of USA and Canada RAS], 11,85-98.

Yaschenko, A. (1912). Istoriya Avstralii [Australian history]. Moscow, tipografiya Imperskogo universiteta, $200 \mathrm{p}$.

Zonthaymer, K. (1996). Federativnaya Respublika Germaniya segodnya. Osnovnyie chertyi politicheskoy sistemy [Federal Republic of Germany today. The main features of the political system]. Moscow, Izdatelstvo Pamyatniki istoricheskoy mysli, $381 \mathrm{p}$. 


\title{
Многовариантность государственной \\ конструкции федерализма \\ (сравнительное историко-государствоведческое \\ исследование)
}

\author{
А.Д. Гуляков \\ Пензенский государственный университет \\ Российская Федерачия, Пенза
}

\begin{abstract}
Аннотация. Статья обосновывает необходимость историко-государствоведческого подхода с помощью анализа моделей федерализма, присущих разным странам. К структурным элементам любой модели относятся предпосылки и причины, способствовавшие федерализации, сущностные характеристики федерализма (в том числе генезисная характеристика, историческая типология, вектор развития), основные этапы развития федерализма.

Используя системный и сравнительный методы, на примере рассмотрения трех первопоселенческих моделей, присущих США, Канаде, Австралии, одной европейской (германской) и российской моделей, автор показывает и объясняет особенности федерализма в упомянутых странах. В частности, отмечаются более благоприятные условия становления федераций в первопоселенческих социумах и известные трудности их утверждения в Европе (на примере Германии). Демонстрируется идеологически новаторский характер советского федерализма и рациональное построение российского (постсоветского) федерализма, не отказавшегося от высокой степени централизации.

Представленные материалы, по мнению автора, не только помогают увидеть новые оттенки в государственной конструкции федерализма, но и способствуют разработке концепции реформирования федеративных отношений.
\end{abstract}

Ключевые слова: федерализм, модели федерализма, первопоселенческий федерализм, европейский федерализм, этапы развития федерализма, сравнительный федерализм.

Научная специальность: 12.00.00 - юридические науки. 